\title{
Priority Systems at Theme Parks from the Perspective of Managers and Customers
}

\section{Gilda Hernandez-Maskivker and Gerard Ryan}

\author{
"People nowadays like to be together not in the old-" \\ fashioned way of, say, mingling on the piazza of \\ an Italian Renaissance city, but, instead, huddled \\ together in traffic jams, bus queues, on escalators \\ and so on. It's a new kind of togetherness which \\ may seem totally alien, but it's the togetherness of \\ modern technology.
}

J. G. Ballard (1930-2009)

Novelist, short story writer, and essayist

\begin{abstract}
Waiting times are becoming an increasingly important customer-experience challenge in theme parks. The seemingly ever-present problem of long queues for rides and attractions is being tackled by the development of priority systems. These innovations allow customers to join an alternative queue that bypasses the congestion faced by regular customers. In other words, by paying extra, customers can purchase the right to be served sooner. Such systems are becoming prevalent, but there is a lack of empirical research into priority systems at theme parks in the academic and management literature, which suggests that in-depth empirical analysis is necessary in order to understand the consumer decision-making process when making this purchase. This article examines priority systems at theme parks both from the viewpoint of park management and of customers. To address this gap, we surveyed nearly 1,000 customers at a major theme park in Spain and conducted semi-structured interviews with 10 theme park managers to assess both customer and manager attitudes towards waiting generally and priority systems specifically. Our results reveal that these priority systems facilitate market segmentation. When theme parks offer this "wait or pay" option, different groups of customers are identified based on their attitudes: those who wait in regular lines and those who are willing to pay to avoid lines. Thus, this innovative system creates an important source of new revenue while also improving the customer experience by reducing waiting times and minimizing congestion. Following a discussion of our results, we offer practical recommendations to managers who need to address the challenges of waiting times in theme parks and wish to improve both profits and customer experiences by implementing a priority system.
\end{abstract}

\section{Introduction}

For more than 30 years, consumer waiting times have been analyzed in different contexts and situations. Tourism services are notably vulnerable contexts for long wait times, particularly at theme parks (Gnoth et al., 2006). As attendance increases in some of the major theme parks around the world (Heo \& Lee, 2009; Milman, 2010), the problem of long queues for rides is everpresent and becoming increasingly urgent (Martin, 2013; Nip, 2014).
Long waiting times and queues are inevitable for theme parks due to operational reasons and the nature of the service. When attraction and ride capacity is exceeded by visitor demand, queues and delays are unavoidable (Dawes \& Rowley, 1996; Heger et al., 2009; Heo \& Lee, 2009; Matthew et al., 2012). Firms focus their efforts on designing and implementing innovations to solve the problem. Many authors have analyzed the phenomenon in order to provide solutions and practical advice to companies and marketers (Davis \& Heineke, 1998; Durrande-Moreau, 1999; Hensley \& Sulek, 2007). These 


\section{Priority Systems at Theme Parks from the Perspective of Managers and Customers} Gilda Hernandez-Maskivker and Gerard Ryan

range from operations solutions (to reduce actual waiting times), to marketing solutions (based on reducing perceived waiting times), to mixed solutions that include elements of both approaches.

However, in spite of these efforts, the problem has not been fully solved and remains a context of active study. Even Disney, the industry leader, demonstrates through its continued innovations aimed at reducing queues that waiting times are still a major issue each year. Despite implementation of innovations such as smartphone applications that help redirect people to less congested areas, games to pass the time while waiting and wristbands systems (that facilitate mobility, transactions and personalized services), people are still waiting. Time spent in queues is time that cannot be spent enjoying attractions: Brooks (2010) found that customers visiting a major theme park with over 40 attractions only have time to enjoy an average of just 10 attractions because of delays and queues. Additionally, when new attractions are launched, controlling waiting times is almost impossible (Cornelis, 2010).

Priority systems (also known as VIP queues, expresspass systems, or fast-line systems) have emerged as a means of overcoming these problems by giving customers an alternative to waiting. Consumers pay a premium to reduce their waiting time by joining a priority queue, thus becoming separated from regular paying customers (Martin, 2013; Milman, 2001; Rafaeli et al., 2005; Setoodeh, 2004). Although priority systems have been implemented worldwide since the early 2000s, and there are priority systems in use in many major theme parks such as Universal Studios, Six Flags, Port Aventura, Knott's Berry Farm, and Legoland, there is still little scientific literature on the subject (Matthew et al., 2012; Tone \& Kohara, 2007).

There is some literature that examines priority systems from a customer's perspective, and it highlights a number of relevant issues. We know that waiting times and queues are one of the main reasons for complaints at theme parks (Martin, 2013). But, some customers are not really that bothered if they have to wait in regular lines, whereas others prefer to avoid waiting at all costs and purchase an express pass whenever the option is available (Sundström et al., 2011). Thus, customers play a key role in wait management and should not be treated as a homogenous group. However, few studies have deeply analyzed customer's attitudes toward express passes. Such systems are also of great interest to theme park managers. Indeed, there seem to be both negative and positive aspects of priority systems for theme park management, which present both opportunities and challenges for operations and marketing.

In this study, we consider the perceptions and opinions on priority systems from the perspectives of both customers and managers. We added the managerial perspective with the purpose of extending our knowledge of the dynamics of wait management from the point of view of a stakeholder that has largely been overlooked in studies on this subject.

This article is organized as follows. First, we examine the relevant literature on priority systems to develop our conceptual framework. Next, we describe our methodology, which included a large survey of theme park customers and in-depth interviews with theme park managers. Then, we present the results from both perspectives. Finally, we discuss the results and offer conclusions and practical recommendations for managers.

\section{Conceptual Framework}

\section{Theme park priority systems}

There are a number of different types of priority system in current use. For instance, a fast pass ticket may be priced according to:

- the number of rides it applies to (e.g., the Fast Lane at Knott's Berry Farm, which allows access to 10 rides)

- the relative amount of waiting time that it is avoided (e.g., the Flash Pass Platinum at Six Flags, which reduces wait time by up to $90 \%$ )

- the number of times a customer can repeat rides (e.g., Universal Express Unlimited, which allows unlimited access to attractions)

- access to specific positions in the attraction (e.g., the Port Aventura Express Premium Gold, which lets visitors ride in the first row on certain rides)

Existing implementations of such systems show that consumers may be willing to pay a considerable fee to jump the line (Wallop, 2010). In some cases, the price of the express pass is equal to or more than the basic entrance ticket. But beyond reducing waiting times and generating new revenues, such systems may also create new opportunities for innovation in theme park services. For example, many theme parks and hotels implement priority systems using smart bracelet systems that facilitate queue jumping via a radio frequency system (RF system). Therefore, the technology used in 


\section{Priority Systems at Theme Parks from the Perspective of Managers and Customers} Gilda Hernandez-Maskivker and Gerard Ryan

these systems can also be used to gather data about the customer experience and enhance it, for instance by improving the flow of visitors and offering personalized services (Hosteltur, 2015).

\section{Customer attitudes toward express passes}

Attitude may be described as a positive or negative feeling about something (Pizam \& Mansield, 1999). The literature considers psychosocial variables such as attitudes when predicting customer behaviours such as purchase intentions (Kim \& Hunter, 1993; Kraus, 1995; Robinson \& Smith, 2002; Vermeir \& Verbeke, 2006). Thus, positive attitudes towards certain products may be the starting point to stimulate consumption (Vermeir \& Verbeke, 2006). In this sense, a positive or a negative attitude toward waiting (and the alternative offered by an express pass) may determine customer purchasing decisions.

A common need in contemporary society is the need to save time. Indeed, this need may go a long way in explaining the popularity of priority systems. Customers who would prefer to use their time efficiently (Lew \& McKercher, 2006) tend to consider waiting as a waste of time (Leclerc et al., 1995). Indeed, Rafaeli, Barron, and Haber (2002) suggest that waiting can be associated with multiple attitudes such as helplessness, anxiety, complacency, agitation, or irritability. Those who have a negative attitude toward waiting times may be more willing to try to avoid them. Indeed, the literature suggests that saving time may be related to greater levels of happiness (Whillans et al., 2016). Thus, marketing innovations that help to allocate time in a more efficient manner and avoid the loss of time are greatly appreciated by some customers (Solomon, 2008).

Prior studies of attitudes to waiting in different service contexts suggest that certain customers may have a positive or relaxed attitude towards waiting (Bennett, 1998; Rose et al., 2003). As Mishra, Mokhtarian, and Widaman (2014) explained, there are customers that have a positive attitude toward waiting and consider it as an opportunity to relax. For some people, money can be more important than time (Friedman \& Friedman, 1997; Heo \& Lee, 2009). For others, time is more important than money (Fischer, 2016). However, there are no empirical studies that examine these assumptions in the specific context of theme parks. Given that attitudes are often considered a precursor to action (Fodness, 1994; Harrill \& Potts, 2002), we assume that a visitor's attitude towards waiting times at theme parks are a key element in the decision to purchase an express pass.

\section{Managerial attitudes towards express passes}

The negative consequences of waiting times on customers are widely recognized by managers (Hwang \& Lambert, 2005; Maister, 1985; Osuna, 1985; Rafaeli et al., 2002). For instance, waiting times may be associated with crowds, noise, and other characteristics that managers normally attempt to control in order to enhance the visitor experience (Solmaz et al., 2015). Waiting may sometimes result in customers abandoning a service (Carmon et al., 1995; Friedman \& Friedman, 1997; Zhou \& Soman, 2003) and may persuade them not to return in the future (Friedman \& Friedman, 1997).

Thus, the management of waiting time becomes a key issue for many service-based companies (Davis \& Heineke, 1998), including providers of tourism services (Dawes \& Rowley, 1996). Hence, companies try to reduce both real and perceived waiting times (Hui \& Tse, 1996; Maister, 1985; Yan \& Lotz, 2006). They may attempt to improve the waiting experience by implementing new systems to reduce real waiting times (Davis \& Heineke, 1994) or they may manipulate contextual factors such as music, information about waiting times, and the social environment (Davis \& Heineke, 1994; Pruyn \& Smidts, 1998). Thus, waiting times may be overestimated or underestimated by customers depending on the strategies implemented to manage the perception of waiting time (Hornik, 1984; Jones \& Peppiatt, 1996; Katz et al., 1991).

Added to this, the literature on theme parks suggests that managers with a positive attitude to reducing waiting times at attractions also demonstrated a positive attitude towards customers as key actors in their future operation policies (Milman, 2001). This relationship suggests that those theme parks that strive to introduce innovations regarding waiting times, such as express passes, are also developing a more customer-oriented strategy. Thus, a customer-oriented perspective of theme parks must be related to new innovations to reduce lines and satisfy customer needs.

Given that managers are obliged to renew companies through constant innovation (Moore, 2003), innovations regarding queue management should act as tools to solve the problem of waiting times and their negatives consequences at theme parks. In addition, to be successful, innovations should positively influence the customer experience (Schumpeter, 1997; Weiermair, 2004). As the literature suggests, customer's attitudes play a determining role in the creation of the customer experience and retail performance (Puccinelli et al., 2009), and therefore must be a focus for innovation. 


\section{Priority Systems at Theme Parks from the Perspective of Managers and Customers} Gilda Hernandez-Maskivker and Gerard Ryan

\section{Methodology}

Given the lack of empirical enquiry surrounding express passes and priority systems at theme parks, we adopted a naturalistic approach in a field setting based on mixed methods. First, 971 survey questionnaires were completed in the surroundings of one of the largest theme parks in Europe (Anton Clavé, 2007). We measured attitudes toward waiting times through three questions about annoyance, stress, and frustration (Bennett, 1998). Each question was measured with a five-point scale. A factorial analysis was conducted in order to group items in a single quantitative variable. As Bennett (1998) suggests in his study of attitudes towards queuing at supermarkets, a control question (five-point scale) was also required: "In general, I really dislike having to wait in queues". Attitude to the express pass was also measured with a five-point scale. A logistic regression model was developed using SPSS software in order to understand tourist behaviour according to factors of influence, such as their attitudes towards waiting times and priority systems. The entry method was applied: explanatory variables are entered into the formula at the same time.

Second, semi-structured interviews were conducted to explore managerial perspectives. Ten managers of major theme parks in Spain were interviewed. The snowball technique was used to contact professionals based on their current activities and their wide experience in managing tourist and leisure services. Because waiting times at theme parks have not previously been analyzed in detail from the point of view of managers.

\section{Results and Discussion}

\section{Customer perspective}

In order to analyze customer behaviour regarding the priority system, a logistic regression model was developed (see Table 1). As Pallant (2013) states, "logistic regression allows you to assess how well your set of predictors variables explains your categorical dependent variable". The results were interpreted, compared, and discussed in relation with prior literature on the subject.

Overall, the results demonstrate the efficacy of the model to differentiate express pass holders from non-holders with an assurance of statistical significance. As Table 1 shows, the goodness-of-fit of the model is ascertained using a Hosmer and Lemeshow goodness-of-fit test, producing a Chi-square (x2) value of 14,484 (with a significance level of 0.07). The non-significance of this value at the 0.05 level means that the fit is appropriate as the observed and predicted classification lacked significant discrepancy. Next, the Ómnibus test of the model's overall Chi-square value $(\mathrm{x} 2=176,479)$ produces a significance of 0.000 , meaning the overall fit is significant. Added to this, the model with the suggested explanatory variables correctly classifies $44.7 \%$ of the express pass holders and $88.1 \%$ of the non-express pass holders. The model has a general explanatory power of $74 \%$ : this is the predictive capacity of the model to correctly classify subjects in two groups (holders and nonholders).

The positive coefficient for the variable "Attitude toward express pass" indicates that customers with a more positive attitude toward the priority systems are more likely to be express pass holders (B: 1,027). This finding is consistent with prior studies explaining that a positive or negative attitude influence on purchase intentions (Kim \& Hunter, 1993; Kraus, 1995; Robinson \& Smith, 2002; Vermeir \& Verbeke, 2006).

As for "Attitude towards waiting", the estimated parameters are positive (B: 0,432). Consequently, the greater

Table 1. Logistic regression model of customer attitudes

\begin{tabular}{lll}
\hline Variables & $\boldsymbol{B}$ & Wald \\
\hline Constant & -4.390 & $146.108^{* * *}$ \\
\hline Gender & 0.149 & 0.883 \\
\hline $\begin{array}{l}\text { Attitude toward priority } \\
\text { systems }\end{array}$ & 1.027 & $111.579^{* * *}$ \\
\hline $\begin{array}{l}\text { Attitude toward waiting } \\
\text { times }\end{array}$ & 0.432 & $27.421^{* * *}$ \\
\hline Ómnibus test & $\mathrm{X}^{2}=176.479^{* * * *}$ & \\
\hline Nagelkerke's R Square & 0.249 & \\
\hline Cox and Snell & 0.179 & \\
\hline -2 Log likelihood & 953.230 & \\
\hline Hosmer and Lemeshow & $\begin{array}{l}\mathrm{X}^{2} 14.484 \\
\text { df } 8\end{array}$ \\
\hline $\begin{array}{l}\text { Sig. } 0.070 \\
\text { Correctly Classified }\end{array}$ & $\mathbf{7 4 . 0 \%}$ \\
\hline
\end{tabular}




\section{Priority Systems at Theme Parks from the Perspective of Managers and Customers}

\section{Gilda Hernandez-Maskivker and Gerard Ryan}

the negative attitude towards waiting times, the higher the probability of customers being express pass holders. These findings are supported by results shown in previous research: customers have varied attitudes towards waiting times (Bennett, 1998; Durrande-Moreau, 1999; Rose et al., 2003). Thus, customers with stronger negative attitudes towards waiting are more likely to want to avoid waiting in queues. In contrast, people with a more positive attitude towards waiting may be more tolerant of queuing in regular lines.

Thus, our results demonstrated that there is a clear opportunity for market segmentation based on customer's attitudes. Attitudes vary towards time (Usunier \& Valette Florence, 2007), waiting times (Mishra et al., 2014), and systems to avoid waiting. In this sense, customer's attitude toward the priority system and their attitudes toward waiting times are significant factors to take into account when characterizing both market segments. Thus, it is possible to segment customers before they purchase the express pass by taking into account those explanatory variables.

\section{Managerial perspective}

According to the data obtained from the interviews with managers, priority systems enable theme parks to satisfy a market segment that is willing to pay to bypass regular lines, thus avoiding unnecessary delays. Our interviews supported previous findings that fast lines reduce customer dissatisfaction with waiting (Heo \& Lee, 2009), they help reduce congestion at theme parks (Tone \& Kohara, 2007), and they improve queue management and customer flows throughout the premises (Heo \& Lee, 2009). Moreover, priority queues contribute to the maximization of the service capacity, enabling operators to ensure demand is constant across service points (Matthew et al., 2012).

Despite the potential negative impact on customer experience, from the point of view of theme park managers, waiting may provide economic benefits to the theme parks. The interviewees explained that there is a positive relationship between long delays and sales of express passes and consequently more revenues for the theme parks, as highlighted by one theme park manager:

\footnotetext{
"Express passes provide a great amount of income. We can say that, thanks to waiting times, we can improve income. The sale of express products is directly proportional to waiting times. This is a great contradiction. It's a great source of revenues that today the theme park can't go without." (Interviewee 1, Theme park manager)
}

Previous studies support this strategy of charging consumers to avoid the wait (Friedman \& Friedman, 1997; Heo \& Lee, 2009; Matthew et al., 2012). The system of fast line passes increases company profits (Friedman \& Friedman, 1997; Heo \& Lee, 2009; Matthew et al., 2012) while improving waiting management and minimizing congestion (Tone \& Kohara, 2007). Indeed, it might be suggested that some theme parks take advantage of this situation. The prices charged for express passes continue to rise, as more people are willing to purchase the service:

"Due to the increased demand for this product, theme parks must raise the price, season after season. They have to do that for two reasons: on the one hand, if people increasingly value the service, it will cost more; and on the other hand, if companies don't raise the price waiting times for priority lines will be longer than waiting times for regular lines."

(Interviewee 2, Theme park manager)

\section{Conclusions and Recommendations}

Theme park managers are aware that waiting times and queues can overshadow the fantasy world of the parks that offer customers a break from the routines and monotony of everyday life by transporting them in time and space (Milman, 1991). Making guests wait may shatter this illusion and lead to substantial customer dissatisfaction (Brown et al., 2013; Wu et al., 2014). If waiting times and queues are present, that entire experience may be interrupted and fragmented. In spite of this, many customers accept and resign themselves to join long queues because they understand that waiting is unavoidable due to operational issues. Yet, it may be unwise to resign oneself to the suggestion that companies cannot improve their experience and provide value during waiting times.

In terms of managerial takeaways, we offer the following practical recommendations based on our study:

1. Managers should take into account customer's attitudes toward waits and priority systems in order to clearly identify the customer segments that are willing to pay extra to avoid queues and provide the necessary services. Express passes should be available for those who are willing to pay. However, both technological and marketing innovations are required to avoid non-express pass holders waiting during a considerable part of their time at theme parks. 


\section{Priority Systems at Theme Parks from the Perspective of Managers and Customers}

\section{Gilda Hernandez-Maskivker and Gerard Ryan}

2. Theme parks should focus their efforts on eliminating queues and waiting times but also on reducing perceived waiting time. Companies should offer alternatives and services for both groups: for those who have positive attitudes and also for those who have negative attitudes toward delays.

3. Waiting times should be considered as one part of the global customer experience and not as residual and wasted time. Companies should manage the waiting experience so that customers do not feel they are waiting, by filling the waiting time with fun and entertaining activities.

4. Theme parks and tourist providers around the world should consider using technology to enhance the customer waiting experience. Thus, technological innovations should be applied to satisfy those who wait in regular lines, offering value to the customer during this time. And also, technology can help companies to design a better service for those who are willing to pay extra to avoid queues.

5. Service design thinking and co-creation approaches should be considered to help managers rethink the waiting time problem and develop tools to solve it. User needs and attitudes have to be taken into account to create value when delivering the service.

6. Theme parks should improve marketing strategies to increase sales of express passes. Marketing strategies should be also oriented to reduce negative connotations regarding the express pass, such as injustice or worthlessness.

This research extends current knowledge on waiting times and priority systems at theme parks. We found that not all visitors behave in the same way when face waiting times and systems to avoid queues, depending on the factors that influence them. There are customers more likely to wait in regular lines and there are others who are more likely to pay extra to avoid waits. However, deeper analyses are necessary in order to understand how customers interpret waiting and the systems used to avoid them. Future research can test other independent variables to advance understanding of the waiting experience and purchase decisions in theme parks. In addition, future studies can explore the customer's decision to pay or to wait in other tourism contexts such as airports, museums, nightclubs, theatres, and events. Future research can also examine issues surrounding equality, social justice, and fairness in services that offer priority queues or express passes.

\section{Acknowledgments}

An earlier version of this article was presented at the 2016 International Conference on Tourism (ICOT) Innovation Conference, which was held in Naples, Italy from June 29 to July 6,2016 , in collaboration with the International Association for Tourism Policy (IATOUR; iatour.net), a non-profit organization dedicated to promoting scientific tourism research.

\section{About the Authors}

Gilda Hernandez-Maskivker is an Assistant Professor in the Department of Business Management at Rovira i Virgili University in Tarragona, Spain. She has a PhD in Tourism and Leisure and a Master's degree in Analytical Techniques and Innovation in Tourism, both from Rovira i Virgili University. Her main research line is on waiting times in tourism services and tourist behaviour. Gilda has also collaborated with the Maldives National University Faculty of Hospitality and Tourism Studies in Malé, Maldives; HTSI-ESADE in Barcelona, Spain; OsteleaEAE in Barcelona; and the European University School for Tourism in Milan, Italy.

Gerard Ryan is an Associate Professor and accredited Full Professor (ANECA, Spain) in Marketing at Rovira i Virgili University in Tarragona, Spain, and he is a Visiting Fellow at Cornell University in Ithaca, USA. He is a founding member of FHOM, which is part of the Catalan government's map of official research groups. He is on the editorial advisory board of the Journal of Research in Interactive Marketing, la Revista Escritos Contables y de Administración, and the Irish Journal of Management. He is a regular reviewer and an award recipient of the Emerald Group for his research. His main research interest are consumers, time, and waiting.

\section{References}

Anton Clavé, S. 2007. The Global Theme Park Industry. Cambridge, MA: Cabi.

http://dx.doi.org/10.1079/9781845932084.0365

Bennett, R. 1998. Queues, Customer Characteristics and Policies for Managing Waiting-Lines in Supermarkets. International Journal of Retail \& Distribution Management, 26(2): 78-87. http://dx.doi.org/10.1108/09590559810206498 


\section{Priority Systems at Theme Parks from the Perspective of Managers and Customers} Gilda Hernandez-Maskivker and Gerard Ryan

Brooks, B. 2010. Disney Tackles Major Theme Park Problem: Lines. The New York Times, December 27, 2010. Accessed November 1, 2016: http://www.nytimes.com/2010/12/28/business/media/28disney.html

Brown, a., Kappes, J., \& Marks, J. 2013. Mitigating Theme Park Crowding with Incentives and Information on Mobile Devices. Journal of Travel Research, 20(10): 1-11. http://dx.doi.org/10.1177/0047287512475216

Carmon, Z., Shanthikumar, J. G., \& Carmon, T. F. 1995. A Psychological Perspective on Service Segmentation Models: The Significance of Accounting for Consumers' Perceptions of Waiting and Service. Management Science, 41(11): 1806-1815. http://dx.doi.org/10.1287/Mnsc.41.11.1806

Cornelis, P. C. M. 2010. Impact of New Attractions on Theme Park Attendance. Worldwide Hospitality and Tourism Themes, 2(3): 262-280.

http://dx.doi.org/10.1108/17554211011052203

Davis, M., \& Heineke, J. 1994. Understanding the Roles of the Customer and the Operation for Better Queue Management. International Journal of Operations \& Production Management, 14(5): 21-34.

http://dx.doi.org/10.1108/01443579410056777

Davis, M., \& Heineke, J. 1998. How Disconfirmation, Perception and Actual Waiting Times Impact Customer Satisfaction. International Journal of Service Industry Management, 9(1): 64-73. http://dx.doi.org/10.1108/09564239810199950

Dawes, J., \& Rowley, J. 1996. The Waiting Experience: Towards Service Quality in the Leisure Industry. International Journal of Contemporary Hospitality Management, 8(1): 16-21. http://dx.doi.org/10.1108/09596119610108608

Durrande-Moreau, A. 1999. Waiting for Service: Ten Years of Empirical Research. International Journal of Service Industry Management, 10(2): 171-185.

http://dx.doi.org/10.1108/09564239910264334

Fischer. 2016. Why Time Is More Important Than Money. Success Magazine, February 22, 2016. Accessed November 1, 2016: http://www.success.com/Blog/Why-Time-Is-More-ImportantThan-Money

Fodness, D. 1994. Measuring Tourist Motivation. Annals of Tourism Research, 21(3): 555-581. http://dx.doi.org/10.1016/0160-7383(94)90120-1

Friedman, H. H., \& Friedman, L. W. 1997. Reducing The "Wait" in Waiting-Line Systems: Waiting Line Segmentation. Business Horizons, 40(4): 54-58. http://dx.doi.org/10.1016/S0007-6813(97)90039-2

Gnoth, J., Bigné, J. E., \& Andreu, L. 2006. Waiting Time Effects on the Leisure Experience and Visitor Emotions. In M. Kozak \& L. Andreu (Eds.), Progress in Tourism Marketing: 255-269. Amsterdam: Elsevier.

Harrill, R., \& Potts, T. D. 2002. Social Psychological Theories of Tourist Motivation: Exploration, Debate, and Transition. Tourism Analysis, 7(2): 105-114.

http://dx.doi.org/10.3727/108354202108749989

Heger, C., Offermans, S., \& Frens, J. 2009. Waiting as Part of the Fun: Interactive Gaming in Theme Park Queues. Offermans SAM, Nagtzaam HA H. Proceedings of SIDER, 9, 52-55.

Hensley, R. L., \& Sulek, J. 2007. Customer Satisfaction with Waits in Multi-Stage Services. Managing Service Quality, 17(2), 152-173. http://dx.doi.org/10.1108/09604520710735173
Heo, C. Y., \& Lee, S. 2009. Application of Revenue Management Practices to the Theme Park Industry. International Journal of Hospitality Management, 28(3): 446-453. http://dx.doi.org/10.1016/j.ijhm.2009.02.001

Hornik, J. 1984. Subjective vs. Objective Time Measures: A Note on the Perception of Time in Consumer Behavior. The Journal of Consumer Research, 11(1): 615-618. http://dx.doi.org/10.1086/208998

Hosteltur. 2015. Pulseras Inteligentes, La Navaja Suiza Del Siglo XXI Para El Turismo. Hosteltur, March 16, 2016. Accessed November 1, 2016: http://www.hosteltur.com/110205_pulseras-inteligentes-navajasuiza-siglo-xxi-turismo.html

Hui, M., \& Tse, D. 1996. What to Tell Consumers in Waits of Different Lengths: An Integrative Model of Service Evaluation. Journal of Marketing, 60(2): 81-90. http://www.jstor.org/stable/1251932

Hwang, J., \& Lambert, C. U. 2005. Customers' Identification of Acceptable Waiting Times in a Multi-Stage Restaurant System. Journal of Foodservice Business Research, 8(1): 3-16. http://dx.doi.org/10.1300/J369v08n01_02

Jones, P., \& Peppiatt, E. 1996. Managing Perceptions of Waiting Times in Service Queues. International Journal of Service Industry Management, 7(5): 47-61. http://dx.doi.org/10.1108/09564239610149957

Katz, K. L., Larson, B. M., \& Larson, R. C. 1991. Prescription for the Waiting-In-Line Blues- Entertain, Enlighten, and Engage. Sloan Management Review, 32(2): 44-53.

Kim, M., \& Hunter, J. 1993. Relationships among Attitudes, Behavioral Intentions, and Behavior. Communication Research, 20: 331-364. http://dx.doi.org/10.1177/009365093020003001

Kraus, S. 1995. Attitudes and the Prediction of Behavior: A MetaAnalysis of the Empirical Literature. Personality and Social Psychology Bulletin, 21: 58-75. http://dx.doi.org/10.1177/0146167295211007

Leclerc, F., Schmitt, B. H., \& Dubé, L. 1995. Waiting Time and Decision Making: Is Time Like Money? Journal of Consumer Research, 21(1): 110-119. http://dx.doi.org/10.1086/209439

Lew, A., \& McKercher, B. 2006. Modeling Tourist Movements: A Local Destination Analysis. Annals of Tourism Research, 33(2): 403-423. http://dx.doi.org/10.1016/j.annals.2005.12.002

Maister, D. H. 1985. The Psychology of Waiting Lines. In M. R. S. J. A. Czepiel \& C. F. Surprenant (Ed.), The Service Encounter: 113-123. Lexington, MA: Lexington Books.

Martin, H. 2013. More Theme Parks Make Sure Waiting in Line Is Long on Fun. Los Angeles Times, August 8, 2013. Accessed November 1, 2016: http://articles.latimes.com/2013/aug/08/business/la-fi-themepark-lines-20130809

Matthew, A., MacLaren, A., O'Gorman, K., \& White, C. 2012. Priority Queues: Where Social Justice and Equity Collide. Tourism Management, 33(4): 875-884.

http://dx.doi.org/10.1016/j.tourman.2011.09.009

Milman, A. 1991. The Role of Theme Parks as a Leisure Activity for Local Communities. Journal of Travel Research, 29(3): 11-16. http://dx.doi.org/10.1177/004728759102900302 


\section{Priority Systems at Theme Parks from the Perspective of Managers and Customers}

\section{Gilda Hernandez-Maskivker and Gerard Ryan}

Milman, A. 2001. The Future of the Theme Park and Attraction Industry: A Management Perspective. Journal of Travel Research, 40(2): 139-147.

http://dx.doi.org/10.1177/004728750104000204

Milman, A. 2010. The Global Theme Park Industry. Worldwide Hospitality and Tourism Themes, 2(3): 220-237. http://dx.doi.org/10.1108/17554211011052177

Mishra, G., Mokhtarian, P., \& Widaman, K. 2014. An Empirical Investigation of Attitudes toward Waiting on the Part of Northern California Commuters. Travel Behaviour and Society, 2(2): 78-87. http://dx.doi.org/10.1016/j.tbs.2014.09.002

Moore, G. 2003. Darwin and the Demon: Innovating within Established Enterprises. Harvard Business Review, 82(7-8): 86-92.

Nip, A. 2014. Waiting Times at Hong Kong Theme Parks Rise as Tourism Increases. South China Morning Post, January 26, 2014. Accessed November 1, 2016:

http://www.scmp.com/news/hong-kong/article/1413797/waitingtimes-hong-kong-theme-parks-rise-tourism-increases

Osuna, E. E. 1985. The Psychological Cost of Waiting. Journal of Mathematical Psychology, 29(1): 82-105. http://dx.doi.org/10.1016/0022-2496(85)90020-3

Pallant, J. 2013. SPSS Survival Manual: A Step by Step Guide to Data Analysis Using SPSS. New York, USA: Open University Press.

Pizam, A., \& Mansield, Y. E. 1999. Consumer Behavior in Travel and Tourism. New York: Haworth Press, Inc.

Pruyn, A., \& Smidts, A. 1998. Effects of Waiting on the Satisfaction with the Service: Beyond Objective Time Measures. International Journal of Research in Marketing, 15(4): 321-334. http://dx.doi.org/10.1016/S0167-8116(98)00008-1

Puccinelli, N., Goodstein, R., Grewal, D., \& Price, R. 2009. Customer Experience Management in Retailing: Understanding the Buying Process. Journal of Retailing, 85(1): 15-30. http://dx.doi.org/10.1016/j.jretai.2008.11.003

Rafaeli, A., Barron, G., \& Haber, K. 2002. The Effects of Queue Structure on Attitudes. Journal of Service Research, 5(2): 125-139. http://dx.doi.org/10.1177/109467002237492

Rafaeli, A., Kedmi, E., Vashdi, D., \& Barron, G. 2005. Queues and Fairness: A Multiple Study Experimental Investigation. Unpublished Work. Haifa, Israel: Israel Institute of Technology.

Robinson, R., \& Smith, C. 2002. Psychosocial and Demographic Variables Associated with Consumer Intention to Purchase Sustainably Produced Foods as Defined by the Midwest Food Alliance. Journal of Nutrition Education and Behavior, 34(6): 316-325.

http://dx.doi.org/10.1016/S1499-4046(06)60114-0

Rose, G. M., Evaristo, R., \& Straub, D. 2003. Culture and Consumer Responses to Web Download Time: A Four-Continent Study of Mono and Polychronism. IEEE Transactions on Engineering Management, 50(1): 31-44.

http://dx.doi.org/10.1109/TEM.2002.808262

Schumpeter, J. 1997. Theorie Der Wirtschaftlichen Entwicklung: Eine Untersuchung üBer Unternehmergewinn. Kredit, Zins Und Konjunkturzyklus, 9th ed. Berlin: Duncker \& Humblot.
Setoodeh, R. 2004. Step Right up!-Amusement-Park Visitors Pay Premium to Avoid Long Lines; Some Have-Nots Are Miffed. Wall Street Journal, July 12, 2004. Accessed November 1, 2016: http://www.wsj.com/articles/SB108959186347560947

Solmaz, G., Akbas, M., \& Turgut, D. 2015. A Mobility Model of Theme Park Visitors. IEEE Transactions on Mobile Computing, 14(12): 2406-2418.

http://dx.doi.org/10.1109/TMC.2015.2400454

Solomon, M. R. 2008. Comportamiento Del Consumidor. México: Pearson Education.

Sundström, M., Lundberg, C., \& Giannakis, S. 2011. Tourist Shopping Motivation: Go with the Flow or Follow the Plan. International Journal of Quality and Service Sciences, 3(2): 211-224. http://dx.doi.org/10.1108/17566691111146104

Tone, T., \& Kohara, K. 2007. A Study of the Effects of Congestion Information and a Priority Boarding Pass in a Theme Park with Multi-Agents. IEEJ Transactions on Electronics, Information and Systems, 127: 407-415. http://dx.doi.org/10.1541/ieejeiss.127.407

Usunier, J. C., \& Valette Florence, P. 2007. The Time Styles Scale - a Review of Developments and Replications over 15 Years. Time Society, 16(2-3): 333-366. http://dx.doi.org/10.1177/0961463X07080272

Vermeir, I., \& Verbeke, W. 2006. Sustainable Food Consumption: Exploring the Consumer "Attitude - Behavioral Intention" Gap. Journal of Agricultural and Environmental Ethics, 19(2): 169-194. http://dx.doi.org/10.1007/s10806-005-5485-3

Wallop, H. 2010. $£ 350$ to Queue Jump at a Theme Park. The Telegraph, June 12, 2010. Accessed November 1, 2016: http://www.telegraph.co.uk/finance/newsbysector/retailandcons umer/7821388/350-to-queue-jump-at-a-theme-park.html

Weiermair, K. 2004. Product Improvement or Innovation: What Is the Key to Success in Tourism. Paper presented at the Innovations in Tourism UNWTO Conference. http://dx.doi.org/10.1787/9789264025028-5-En

Whillans, A. V., Weidman, A. C., \& Dunn, E. W. 2016. Valuing Time over Money Is Associated with Greater Happiness. Social Psychological and Personality Science, 7(3): 213-222. http://dx.doi.org/10.1177/1948550615623842

Wu, H., Li, M., \& Li, T. 2014. A Study of Experiential Quality, Experiential Value, Experiential Satisfaction, Theme Park Image, and Revisit Intention. Journal of Hospitality \& Tourism Research, 20(5): 1-48.

http://dx.doi.org/10.1177/1096348014563396

Yan, R., \& Lotz, S. 2006. The Waiting Game: The Role of Predicted Value, Wait Disconfirmation, and Providers' Actions in Consumers' Service Evaluations. Advances in Consumer Research, 33: 412-418.

Zhou, R., \& Soman, D. 2003. Looking Back: Exploring the Psychology of Queuing and the Effect of the Number of People Behind. Journal of Consumer Research, 29(4): 517-530. http://dx.doi.org/10.1086/346247 